\title{
Museums as Sites of Critical Pedagogical Practice
}

\section{Peter Mayo}

To cite this article: Peter Mayo (2013) Museums as Sites of Critical Pedagogical Practice, Review of Education, Pedagogy, and Cultural Studies, 35:2, 144-153, DOI: 10.1080/10714413.2013.778661

To link to this article: http://dx.doi.org/10.1080/10714413.2013.778661

曲 Published online: 02 May 2013.

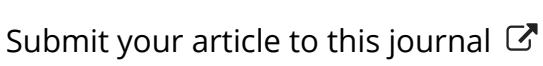

Lll Article views: 277

Q View related articles $\asymp$

4 Citing articles: 1 View citing articles ๔ 


\title{
Museums as Sites of Critical Pedagogical Practice
}

\author{
Peter Mayo
}

\section{INTRODUCTION}

Paulo Freire's notion that education is politics is well known to readers involved in areas of critical education, and thus a detailed rehearsal of the burgeoning literature illustrating and elaborating on this view is not necessary. After all, this view has a very long, albeit repressed, history, which anticipates Freire and those who took up the legacy of his thought and action; suffice to mention, for example, work connected with "independent working class education"" (Simon 1992; Waugh 2009). Significant for my purposes, however, is that an approach to education-such as Freire's, which fore-grounds the histories and unique experiences of industrial working class and other subaltern groups-is capacious and yet critical enough to incorporate several sites of learning, including libraries, coffee shops (as in Cyprus), mining pits ("reading Capital in the pit") ${ }^{1}$ and sporting arenas. In what follows, I want to extend this notion of education to include museums, which I suggest are an important and productive site for practicing critical pedagogy.

\section{CRITICAL PEDAGOGY}

This democratized notion of education is broad enough to include what Henry Giroux (2005) calls sites of "public pedagogy." These public pedagogic sites range from schools, to cinemas and youth entertainment areas, and are often deeply informed by consumerist and militarized ideologies. Giroux uses the term public pedagogy to critique the devastating effects and "terror" of neoliberal policies, and when arguing for universities, schools, and other learning agencies to serve as democratic public spheres. Similarly, Michael Apple (1993) argues for curricular democratization, which he suggests is a site of contestation that mirrors other sites of struggle, such as the state and textbook industries. Apple details the economic, political, and ideological processes that enable specific groups' knowledge to become "official" whereas other groups' knowledge become "popular" (1993). Likewise, Antonia Darder has consistently engaged 
issues of cultural democracy and notions of culture and power, particularly in conditions of learning in disenfranchised and racialized communities (2011). These writers practice an approach to education known as critical pedagogy, which is defined by one of its major exponents, Peter McLaren, as a project "fundamentally concerned with the centrality of politics and power in our understanding of" education and learning (1994). Critical pedagogy is very much inspired by Freire, a great source of influence among the contemporary writers just mentioned.

\section{MUSEUMS}

Educational sites are multiple and therefore it is possible to adopt a critical pedagogical perspective in areas that rarely feature in the ever-burgeoning literature on or inspired by the ideas of the Brazilian educator. In this chapter, I focus on a topic that a close colleague, Carmel Borg, and I have addressed in a number of articles over the last few years (Borg and Mayo 2000a, 2000b, 2010; Borg, Cauchi, and Mayo 2005; Mayo 2009; English and Mayo 2012). Examples from the international literature would include labor museums in the U.K. (see English and Mayo 2012), which have played an important role in independent working class education, especially with regard to trade unions (Spencer 2005), and which I consider to be an important site of cultural politics and public pedagogy. As Carmel Borg and I have suggested, the situation concerning museums is not so far removed from that regarding the curriculum. We argue that the curriculum works to provide legitimacy to some forms of knowledge to the detriment of other forms (Borg and Mayo 2000b, 81), which echoes Apple's writing on the curriculum. We argue that "museums have a similar role [to curricula]. Like established curricula, they too give legitimacy to particular forms of cultural production, creating 'official knowledge'... [and] are caught up in the politics of knowledge and representation" (Borg and Mayo 2000b, 81).

\section{SELECTION FROM CULTURES}

We insist that museums, like curricula, depict selections from the cultures of society (to slightly modify Dennis Lawton's statement inspired by Raymond Williams). This leads the critical viewer or museum educator to challenge the "cultural arbitrariness" of museum exhibits, and hopefully to refrain from viewing museums as repositories of so-called neutral knowledge (Borg and Mayo 2000b). In our work we note the Eurocentric and class bias of museums by discussing Maltese museums, as well as some international museums, for instance, the Museum of Modern Art (MOMA), and the American Crafts Museum, which are situated across the road from each other in New York City. The juxtaposition of what strikes us as highbrow cultural production, on the one hand, and subaltern and popular production, on the other, renders questions and considerations associated with critical pedagogy most relevant: 
MOMA (Museum of Modern Art) in New York houses paintings, sculpture, architectural displays ... displays of aspects of film history and a display of designs of cars, modern furniture and office equipment. The last mentioned are strongly associated with the corporate world, whereas the designs of different crafts (e.g., the work of the Women of Colour Quilters Network) are displayed in a different museum (the American Craft Museum) across the road from MOMA. The debate regarding whether such forms of cultural production should be separated or not is an important feature of the "culture wars" that have characterized the struggle for democratic renewal in North America. These "wars" often revolve around class, gender, race and ethnicity issues. They can easily revolve around issues relating to production, e.g., corporate power on the one hand and subsistence economies or cooperatives on the other. (Borg and Mayo 2000b, 86)

What we are confronted with here are cultural productions deriving from two different social milieus: dominant and the subaltern classes. As with the mainstream curriculum, we witness a politics of inclusion and exclusion. Debates about political inclusion and exclusion can, however, take place within a critical pedagogical setting, in other places. In any museum, for example, questions can be raised about what gets included and what is left out. Who is represented in an art museum and who does not find his or her place there? Who is represented in the mainstream institution and who is confined to a Salon des Refusés. A critical pedagogical approach becomes relevant here because it poses meaningful questions, such as, "Whose culture shall be the official one and whose shall be subordinated? What culture shall be regarded as worthy of display and which shall be hidden? Whose history shall be remembered and whose forgotten? What images of social life shall be projected and which shall be marginalized? What voices shall be heard and which will be silenced? Who is representing whom and on what basis?" (Jordan and Weedon $1995,4)$.

\section{IRONIC JUXTAPOSITION}

Other museums are less exclusionary in their exhibits and thus do in fact raise some of these questions, which arouses a sense of irony. The Kelvingrove Art Gallery and Museum in Glasgow, Scotland strikes me as a perfect example of a site that raises such questions. It can do this because it is not exclusively an art museum or social history museum, in the strictest sense, but rather is a combination of both and more. For example, paintings representing a people as victims of oppression are juxtaposed with artifacts attesting to this same people's involvement in the oppression of others. Thus, conflict, contradictory forms of consciousness and morality, and social class ennui, reflected in family gender relations, are made available for critical engagement. This type of museum could be a meaningful and transformative site for critical educators. Moreover, its trans-disciplinary approach to knowledge and history assists in the process of a substantive critical pedagogy. However, we would argue that while perhaps requiring a greater effort and sensitivity on the part of the educator and visitor/learner, even more conventional, "Victorian," and staid museums can act as equally important sites for the practice of critical pedagogy. 


\section{RENEGOTIATING RELATIONS OF HEGEMONY}

The Museum offers us opportunities not only for ideology critique, in the sense expounded by members of the Frankfurt School, but also for struggling collectively and lobbying for the conversion of such sites of public pedagogy into democratic, inclusive public spaces, which appeal to one's sense of criticality. In short, part of the quest for museum renewal lies in the struggle to renegotiate relations of hegemony. Although museums, like other established institutions constituting what Gramsci conceives of as "civil society" are selective in a manner not politically innocent, they can be conceived of as sites of struggle, cultural contestation, and renewal (Borg et al. 2003).

Institutions are not monolithic and this certainly applies to museums. While museums can play a part in cementing cultural hegemony, they can also contain some of the seeds for renegotiating hegemonic relations. Like schools, museums are culturally selective, often decontextualizing artifacts by extricating them from their original surroundings. Museums could, however, be conceived of the way Freire, Giroux, Darder, Apple, and other critical pedagogues conceive of schools and other institutions - sites of contestation and reconstruction. In studies with colleagues Carmel Borg, Bernard Cauchi, and, more recently, Leona English, I focused on specific types of museums, notably ethnographic museums as well as maritime museums. One study (Borg et al. 2005) deals with Malta's national maritime museum, which is located in a region closely connected to the country's maritime history. The museum is surrounded by a community that includes elderly members who, in their younger years, earned their living at sea at a time when a substantial part of the country's economy revolved around the British naval presence in Malta.

\section{MUSEUMS AS POPULAR PUBLIC SITES}

Besides providing an account of its permanent exhibition, we also explore possibilities for this museum to develop into a popular public place. Doing so would mean embracing the voices of the subaltern and not only those of dominant groups, which are typically reflected in memorabilia, models, and uniforms belonging to the time of either the ruling Sovereign Military Order of St. John or the colonizing British occupational force. We argue that space should be accorded to the "universe of knowledge" of common folk who engage in recreational pursuits and specific forms of creative cultural production that can be traced back to the surrounding maritime cultural milieu. We suggest, for instance, that ample space be accorded to representations connected with the popular regatta (rowing contests held on September 8 and March 31, both national feast days), events that capture the popular imagination in the country's harbor area.

Among other things, our work proposes the use of recent technology to capture the oral popular history of this region, thus giving prominence to the voices of those who for too long have been immersed in what Freire might call the "culture of silence:" 
Oral history offers great opportunities for capturing the authentic voice of the seafaring community that traditionally belonged to the localities surrounding the Malta Maritime Museum. The community where the Museum is situated provides an invaluable wealth of real Maritime experiences. There are no indications within the Maritime museum of an urgency to record and share such genuine experiences. (Borg et al. 2003, 105)

Furthermore, the display concerning what was, for several years, the major source of livelihood in this region ${ }^{2}$ and in the country, namely the Dockyard, is also found lacking when it comes to the affirmation and representation of subaltern popular voices. We argue:

The section in question also overlooks a very important aspect of critical and emancipatory museology, namely the concept of voice. Within the dockyard display, expert knowledge is privileged over other community-based ways of knowing. The harsh reality of dockyard life, the disabilities endured through years of exhaust inhaling, grit blasting and other dangerous emissions, the death of several workers, the various struggles for worker emancipation, the anxiety generated by intermittent work, are basically sanitised in a display which fails to foreground real faces and genuine voices. Secondary sources were privileged over the primary source of the workers' voice. (Borg et al. 2003, 104)

The Dockyard's employees were, for several years, the nearest thing the country had to an industrial working class. While the role of the dockyard workers is immersed in the history of Maltese class struggle and labor politics, much of this history has been concealed or sanitized in the display. For instance, there is little about the role of women as part of the seafaring community; for example, the experience of poverty and destitution resulting from intermittent work, widowhood caused by tragic deaths, solitude as a result of the spouse's long trips at sea, washing sailors' clothes for a pittance and at piece rate, religious vows for safe return of spouses and offspring, prostitution, and so on (Borg and Mayo 2010, 39; English and Mayo 2012, 104).

These are just a few of the suggestions that emerge from our research concerning museums that are conceived of as sites of cultural politics. These suggestions are not meant to detract from the fine work that characterizes museums such as the National Maritime Museum of Malta; work that testifies to the commitment of a very energetic, enterprising, knowledgeable, and dedicated group of museum personnel. On the contrary, there is much to be applauded. As with all small entities lacking the specializations they require, these museums assume multifunctional roles (Hooper-Greenhill 1995, 51). As such, they should be commended for helping develop this museum into one that, in my view, compares well with several maritime museums found in Europe, for instance, the National Maritime Museum in Antwerp, and the Torre del Oro on the banks of Seville's Rio de Guadalvivir. The National Maritime Museum has a dynamic and active staff, which is what makes it such a dynamic museum. The suggestions we make are meant to provide signposts towards rendering museums more democratic, and, in Freire's words, "popular public" spaces-sites of democratic public pedagogy. 


\section{CODIFICATIONS}

We view the various elements on display in these museums as codifications that can serve as the basis for a discussion of wider issues concerning different aspects of the country's historic, social, and political reality. Rather than simply indulging in ideology critique, the museum educators qua critical pedagogues avail themselves of the limitations of a Folklore museum - such as the one situated in a village in Gozo. Doing so helps to develop a problem posing approach to the museum experience, and thus works to prevent the visitor from engaging in what Borg and I have described elsewhere as a "nostalgic trip to a much simpler world" (Borg and Mayo 2000b, 86). As we suggest, the critical educator

provides opportunities for confronting a range of socio-economic issues associated with the exhibits. Thus, for example, a room containing traditional fishing implements can stimulate discussions on the loss of fishing communities, the deskilling of fishermen through technology, fishing wars in the Mediterranean, sea pollution, overfishing and malpractices in fishing, the depletion of fishing stocks, the economic, ecological and social effects of fishing farms ... Such discussions not only challenge the traditional status of the objects, as conveyors of static knowledge with no connection with the present... but also problematise the myth that such objects are culturally neutral and value free. (Borg and Mayo 2000b, 86)

The process should be one in which the educator does not treat the visitor as an empty receptacle to be filled with images and knowledge, and therefore as an object of the cultural transmission process. This is not to suggest, however, that the visitor is ever a passive recipient of knowledge. Neither should one assume that the visitor requires a critical museum educator to engage in a critical reading of the texts on display, which could possibly come across as patronizing. Many visitors do this irrespective of any pedagogic promptings. What we do call for, however, is the development of the museum and other centers as democratic public spaces (Giroux 2001) that allow possibilities for different meanings to be exchanged, appropriated, and negotiated. This will hopefully enable the visitor to become a subject in a process of coinvestigation; one involving the museum educator and the visitor and mediated by the exhibit itself. In such a context, knowledge is not static but dynamic; resulting from dialogue between the museum educator and visitor, and informed by the objects of coinvestigation.

\section{CONFRONTING THE "HIGHBROW"}

The above discussion suggests popular forms of knowledge ought to play a significant role in museums. However, a critical approach to museum education also needs to entail a critical confrontation with the "highbrow," a confrontation we suggest is missing from the archive of critical pedagogy, including work by Paulo Freire.

Our joint work has focused on so-called sites of "highbrow" culture. For example, we write about the seventeenth-century Baroque church, St. John's co-Cathedral, in Malta's capital city, Valletta, which houses paintings by 
Caravaggio, Mattia Preti, and sculptures by Alessandro Algardi, among others. We argue (Borg and Mayo 2000a) that these centers offer ideal spaces for a critical reading of a country's much-heralded artistic heritage. Often reflected in this patrimony is an unmistakably Eurocentric, masculinist (male-aggrandizing), and racist politics of representation which, though calling for a historicist interpretation of events, can still prey on popular sensibilities. We refer, for instance, to the representation of the Saracen "other" in sculptures and carvings. Alterity is here rendered "exotic," often in a highly exaggerated manner. The figures concerned become an integral part of the ostentatious Baroque setting.

\section{POLITICS OF EXTERMINATION AND DISPOSABILITY}

Questions can also be raised about the sinister side of some of the relics, polyptychs, and other items adorned in precious mineral resources such as gold and silver, which are on display in churches such as those discussed above. With the work of Eduardo Galeano (2009) in mind, one can question the provenance of the gold and silver in question, the role of slavery in this context, and the subjugation and extermination of thousands of indigenous people and imported slaves which occurred in the process of extracting mineral resources from the mines of Protosí in present day Bolivia, other parts of Latin America, and elsewhere. Early forms of mining for these resources led to entombment (mentioned also by Marx in Capital Vol. 3), death, and disabilities resulting, for instance, from the use of mercury. Moreover, Seville is the city that housed the strong-room (Casa de Contratación) for the gold and silver that came from Latin America into Spain through the ports of Cadiz. In fact, large portions of precious mineral resources were shipped to Northern countries whose banks had a hold over Spain because of debts incurred, and this contributed significantly to Europe's economic development: "The Spaniards owned the cow, but others drank the milk" (Galeano 2009, 23).

Apart from its impressive gold "retablo mayor" (major polyptych), with 48 panels representing episodes from the life of Christ (the irony cannot be lost here), Seville's Cathedral houses a tomb believed to contain the remains of Cristobal Colón (Christopher Columbus). This is the navigator who best symbolizes the start of what many, reacting to the Columbus celebrations in 1992, regarded as 500 years of genocide in the Americas; his surname constituting a watershed in the history of these lands: pre-Columbine and post-Columbine. A critical pedagogical approach to museums of this kind (many churches in Europe are not only religious places but also museums that tourists and other visitors are allowed to enjoy at a fee) necessitates a critical confrontation with the highbrow and raising unsettling but important historical questions that have been ignored or erased from collective memories. Critical pedagogy raises questions concerning who was and still is deemed worthy of living and of being exterminated (sociologist Zygmunt Bauman [2006] refers to political forms of disposability and extermination as "human waste disposal"), thus working to link the past and present in a dialectical manner. The same way of thinking that led the conquistadors to dispose of indigenous lives many years ago persists today among 
those who exterminate natives of the Amazon in a contemporary rapacious neo-colonial pursuit of rich resources (Galeano 2009), and in the minds of those adolescents who set on fire the sleeping body of a Pataxo native in Brazil (Galdino Jesus dos Santos), which is the subject of a reflective piece by Freire (2000).

Similar questions can be posed with regard to repositories of silver, such as the collection at the Victoria and Albert Museum, in London. Further, they can also be posed with regard to various displays of First Nations art in Canadian museums, such as the Royal BC Museum in Victoria, British Columbia, or the Glenbow Museum, in Calgary, Alberta. These exhibits work pedagogically to sanitize histories of brutal subjugation and extermination of natives, and, as such, do not shed critical light on still extant and thriving companies, which prospered from the fur trade and contributed to the devastation of indigenous populations. Likewise, similar questions can be posed of Risorgimento (Resurgence or Italian Reunification) museums in Italy, such as the one housed inside the base of the Altare della Patria (Altar of the Motherland) in Rome. In this case, one can pose questions concerning the extermination of meridionali (Southerners) by the Piedmontese in a process of violent internal colonialism, which was denounced by Gramsci in his writings on the Southern Question and notes on Italian history, and, more emphatically, in so far as the violence and thinking behind it goes, in an Italian bestseller by Pino Aprile (2010). Both Gramsci and Aprile provide historical accounts of the Risorgimento that are a far cry from the sanitized and romanticized ones I encountered in my school textbooks. In a 2011 sequel, Aprile refers to a Turin museum containing admittedly widely denounced "scientific" displays (they center around the work of Cesare Lombroso, the nineteenth-century Italian criminologist and physician) concerning the purported connection between the mental and physical characteristics of Southerners and their propensity toward criminality and savagery (Aprile 2011, 375-377), which brings to mind the kind of scientific racism exposed by Frantz Fanon in The Wretched of the Earth $(1963,296)$.

Based on the types of critique addressed above, we suggest that critical pedagogy differs from more conventional educational experiences in museums insofar as it focuses not only on purportedly ahistorical "things of beauty" but more importantly on the tragic and violent histories that lurk beneath those things.

\section{CONCLUSION}

In this chapter, I have shown how museums can serve as sites for the practise of critical pedagogy, or, more specifically, critical public pedagogy. These are sites in which, as Freire famously noted, people can learn to read the world-and not just the word-critically. Some museums have greater potential to do this than others and can be more representative in the forms of cultural production they display and hence more socially accessible, particularly to members of subaltern groups. Social and physical accessibility are two issues that are central in collaborative work with my colleagues (see Borg and Mayo 2000b). Museums, however, have potential for developing the kind of popular and working class knowledge that is given prominence in work by Freire and other critical pedagogues. 
There remains the challenge of transforming museums, which have traditionally been repositories of a dominant culture, for example traditional art galleries, into democratic and accessible public spaces. Perhaps modern art galleries provide a stiffer challenge here than those specialising in "old masters" whose names conceal the presence of women working inside convents, studios, and so on, and who remain anonymous, save for an Artemisia Gentileschi, a Lavinia Fontana, a Rosalba Carriera, an Elisabeth Vignée Le Brun or, much later, a Mary Cassatt. The challenge for critical museum pedagogues and those with whom they work is to unmask class, gender, racial, and colonial politics. Without rendering it an object of domination, they would make this alternative knowledge accessible to subaltern groups.

\section{NOTES}

1. Information obtained from former National Union of Mineworkers organizer.

2. This is the Cottonera region that is closely connected to the island's Grand Harbour.

\section{REFERENCES}

Apple, M. W. (1993). Official Knowledge: Democratic Education in a Conservative Age. New York: Routledge.

Aprile, P. (2010). Terroni: Tutto Quello che è stato fatto perche gli Italiani del Sud diventassero Meridionali [People Who Work the land. All That Was Made for Italians from the South to become Southerners]. Milan, Italy: Piemme.

Aprile, P. (2011). Giù al Sud-perche i Terroni salveranno l'Italia [Down in the South. Why the Terroni Will Save Italy]. Milan, Italy: Piemme.

Bauman, Z. (2006). The Crisis of the Human Waste Disposal Industry. In D. Macedo \& P. Gounari (Eds.), The Globalization of Racism (pp. 36-40). Boulder, CO: Paradigm Publishers.

Borg, C. and Mayo, P. (2000a). Malta. In A. Chadwick \& A. Stannett (Eds.), Museums and Adults Learning: Perspectives from Europe (pp. 103-114). Leicester, UK: NIACE.

Borg, C. and Mayo, P. (2000b). Museums, Adult Education and Cultural Politics. Malta. Education $\mathcal{E}$ Society, 18(3), 77-97.

Borg, C. and Mayo, P. (2010). Museums: Adult Education as Cultural Politics. In E. W. Taylor \& M. McKinley Parrish (Eds.), Adult Education in Cultural Institutions: Aquariums, Libraries, Museums, Parks, and Zoos. New Directions for Adult and Continuing Education (Series No. 127); pp. 35-44. San Francisco: Jossey Bass.

Borg, C., Cauchi, B., \& Mayo, P. (2003). Museums, Education and Cultural Contestation. Journal of Mediterranean Studies, 13(1), 89-108.

Darder, A. (2011). Dissident Voices. New York \& Frankfurt, Germany: Peter Lang.

English, L. and Mayo, P. (2012). Learning with Adults: A Critical Pedagogical Introduction. Rotterdam, The Netherlands \& Taipei, Taiwan: Sense Publishers.

Fanon, F. (1963). The Wretched of the Earth. New York: Grove Press.

Freire, P. (2000). Pedagogia da Indignação: Cartas Pedagógicas e Outros Escritos. São Paulo, Brazil: Editora UNESP.

Galeano, E. (2009). Open Veins of Latin America. London: Serpent's Tail.

Giroux, H. A. (2001). Public Spaces/Private Lives. Beyond the Culture of Cynicism. Lanham, MD: Rowman \& Littlefield.

Giroux, H. A. (2005). Schooling and the Struggle for Public Life: Critical Pedagogy in the Modern Age (2nd updated ed.). Boulder, CO: Paradigm.

Hooper-Greenhill, E. (1995). A Museum Educator's Perspective. In A. Chadwick \& A. Stannett (Eds.), Museums and the Education of Adults (pp. 49-64). Leicester, UK: NIACE. 
Mayo, P. (2009). Liberating Praxis. Paulo Freire's Legacy for Radical Politics and Education. Rotterdam, The Netherlands \& Taipei, Taiwan: Sense Publishers.

McLaren, P. (1994). Life in Schools. An Introduction to Critical Pedagogy in the Foundations of Education. New York \& London: Longman.

Simon, B. (Ed.). (1992). The Search for Enlightenment. Adult Education and the Working Class. Leicester, UK: NIACE.

Spencer, B. (2005). Labor education. In L. M. English (Ed.), International Encyclopedia of Adult Education (pp. 339-344). Basingstoke, UK \& New York: Palgrave Macmillan.

Waugh, C. (2009). Plebs. The Lost Legacy of Independent Working Class Education [Occasional paper]. Sheffield, UK: Post 16 Educator. 